\title{
Uterine lymphangiography: comparison of two methods for locating the medial iliac lymph node ${ }^{1}$
}

\author{
Rebeca C. Justino ${ }^{2}$, Guilherme S. Cardoso ${ }^{2}$, Luiz G.C. Trautwein ${ }^{2}$, Gabriel T. Dessunti ${ }^{2}$, \\ Deise V. Oliveira ${ }^{2}$, Rafael Bernardes ${ }^{2}$ and Maria Isabel M. Martins ${ }^{2 *}$
}

\begin{abstract}
Justino R.C., Cardoso G.S., Trautwein L.G.C., Dessunti G.T., Oliveira D.V., Bernardes R. \& Martins M.I.M. 2014. Uterine lymphangiography: comparison of two methods for locating the medial iliac lymph node. Pesquisa Veterinária Brasileira 34(11):11211126. Departamento de Clínicas Veterinárias, Universidade Estadual de Londrina, Rodovia Celso Garcia, Londrina, PR 86061-900, Brazil. E-mail: imartins@uel.br

Different methods for lymphatic mapping in dogs, such as infusing tissues with vital dyes or radioactive substances, have been studied, aiming at the early detection of lymph node metastasis. Thus, one could anticipate therapeutic measures and, consequently, prolong the survival and improve the quality of life of the patients. The objectives of this experiment were to locate the nodes responsible for draining the uterine body and horns and to try to establish the relationship between the uterus and the medial iliac lymph nodes to contribute to the early diagnosis and prognosis of uterine disorders. We studied 15 female dogs divided into two groups ( 5 dead and 10 intraoperative ovariohysterectomy bitches). The dye used was patent blue V (Patent Bleu $V^{\circledR}$ ). It was observed that the iliac lymph node chain receives much of the uterine (horns) drainage. This method should be considered for safer studies of uterine sanity. This information suggests that evaluating these lymph nodes will allow correlating changes in their physiological status with uterine pathologies.
\end{abstract}

INDEX TERMS: Sacral lymph node, aortic lymph node, vital dye, bitches.

RESUMO.- [Linfangiografia uterina: comparação de dois métodos para localização do linfonodo ilíaco medial.] A utilização de diferentes métodos para o mapeamento linfático em cães, como a infusão de substâncias radioativas e corantes vitais em tecidos, tem sido estudada, tendo como objetivo a detecção precoce de metástases em linfonodos. Com isso pode-se antecipar medidas terapêuticas e, consequentemente, prolongar sobrevida e melhorar qualidade de vida dos pacientes. Os objetivos deste experimento foram localizar os linfonodos responsáveis pela drenagem dos cornos e corpo uterino da cadela e tentar estabelecer relação entre útero e linfonodos ilíacos mediais com a finalidade de contribuir para o diagnóstico precoce e prognóstico das afecções uterinas. Foram estudadas 15 cadelas divididas em 2 grupos ( 5 cadáveres e 10 cadelas no transoperatório de ovariohisterectomia). 0 corante utilizado foi

\footnotetext{
${ }^{1}$ Received on December 6, 2013.

Accepted for publication on July 4, 2014.

${ }^{2}$ Departamento de Clínicas Veterinárias, Centro de Ciências Agrárias, Universidade Estadual de Londrina (UEL), Rodovia Celso Garcia PR-445 Km 380, Campus Universitário, Cx. Postal 10011, Londrina, PR 86057970, Brazil.*Corresponding author: imartins@uel.br
}

o azul patente V (Bleu Patente ${ }^{\circledR}$ ). Pôde-se observar que a cadeia de linfonodos ilíacos recebe grande parte da drenagem uterina (cornos) e pode ser considerada em estudos para a sanidade deste órgão. Essa informação permite inferir que a avaliação desses linfonodos possibilita a correlação da alteração em seu padrão fisiológico com patologias uterinas.

TERMOS DE INDEXAÇÃO: Linfonodo sacral, linfonodo aórtico, cadelas, corante vital.

\section{INTRODUCTION}

Initially, the studies aimed at detecting lymphatic drainage pathways involved dissections, which led to several publications that were the basis for anatomy books (Baum 1918). Later, radiographic contrast studies using radiopaque substances, such as ethiodol, were performed (Fischer \& Zimmerman 1959, Skelley et al. 1964). Moreover, many investigations have been conducted to establish techniques for locating the sentinel nodes (Gould et al. 1960, Wong et al. 1991).

Infusing a blue dye (methylene blue or isosulfan blue patent) into tissue allows visualization of the lymphatic 
vessels and lymph nodes and has been used since the beginning of the last century (Rouviere \& Valette 1937). Due to the dye's affinity for lymphatic pathways, it progresses through the channels, and the uptake of the dye by the macrophages in the lymph nodes allows their visual identification (Freitas 2007). This process is due to two basic principles of lymphatic physiology, the existence of an orderly and predictable pattern of drainage to a regional lymph node and the characteristic filtering function that the first ganglion performs (Tanis et al. 2001).

Although the uterine lymphatic drainage of bitches has been known since the studies of anatomists in the nineteenth century, only one study has been performed to reproduce the functional pathway of particles and microorganis$\mathrm{ms}$ from the organ in question to the first lymph nodes to which it drains (Wang et al. 2001).

Due to the high incidence of uterine cancer in humans, several studies have been conducted in attempts to gain more accurate knowledge of the lymphatic system of this region (Altgassen et al. 2007, Bin Li et al. 2007, Burke et al. 1996, Echt et al. 1999, Levenback et al. 2002). Uterine malignant neoplasms are rare in dogs, most of which are discovered as incidental findings at autopsy (Klein 2007). Some papers have reported the occurrence of hemangiosarcomas, adenocarcinoma and leiomyosarcoma (Cave et al. 2002, Tivers et al. 2009, Tsioli et al. 2011).

In contrast, cases of infection and inflammation of the canine uterus are very common (Fontaine et al. 2009, Pretzer 2008, Watts et al. 1998), partially due to the physiology of the reproductive cycle, in which this organ is exposed to the hormone progesterone for a particularly long period (Johnston et al. 2001). Although the etiology of endometritis is not entirely clear, it is associated with infertility in the bitch (Fontaine et al. 2009). Studies have intensified in an attempt to establish reliable prognostic factors that might also be used to reach an early diagnosis of uterine diseases, before complications result (Weiss 2004, Sant'Anna 2012, Mir et al. 2013).

It is known that each lymph node receives drainage from specific regions of the body and responds in a particular manner to each type of disease (cancer, infections by microorganisms, autoimmune diseases) (Cowell et al. 2003). Reactive or hyperplastic lymph nodes receive this classification due to the historic increase of the same and lymphoid proliferation in response to antigenic stimulation (Cowell et al. 2003).

Most likely because uterine malignant neoplasias are rare, few studies of the uterine lymphatic drainage of the bitch have been conducted in the last decades. However, one must also consider common uterine disorders such as endometritis, which may present subclinically.

Assessment of sentinel lymph nodes by observing changes in their characteristics in cases of inflammation, infections and uterine cancers in dogs could facilitate early diagnosis and prognosis and establish patterns for utilization in non-invasive auxiliary exams. Therefore, the objectives of this experiment were to locate the nodes responsible for draining the uterine body and horns of the bitches and to try to establish a relationship between the uterus and the medial iliac lymph nodes to contribute to the early diagnosis and prognosis of uterine disorders.

\section{MATERIALS AND METHODS}

The study was approved by the animal ethics committee of the institution, the Ethics Committee on the Use of Animals, Universidade Estadual de Londrina ( $\mathrm{n}^{\mathrm{o}}$ 183/12). All of the procedures were authorized by the owners of the dogs.

We used 15 mongrel healthy bitches, 1 to 15 years old, weighing between 6 and $15 \mathrm{~kg}$, which belonged to clients of the Veterinary Hospital of the State University of Londrina. These animals were divided into two distinct experimental groups, the first formed by five bitches from the emergency care sector, which were recently euthanized due to indications of irreversible complications in systems other than the reproductive system, and the second consisting of 10 bitches intended for elective castration. The dye used was the Patent Bleu V $®$ (Manufactured by: Delpharm Tours, Chambray Les Tours, France). According to the patient information leaflet, Patent Bleu V $₫$ is a sterile aqueous solution of patent blue $\mathrm{V}$ at a concentration of $2.5 \%$ in buffered monosodium phosphate and made isotonic by the addition of sodium chloride.

In the experiments using cadavers, immediately after euthanasia, the abdominal cavity was accessed, and the uterus located and isolated. An aliquot of $0.2 \mathrm{~mL}$ of patent blue was injected into the middle portion of each horn and into the uterine body, totaling $0.6 \mathrm{~mL}$ (Fig.1). After 10 minutes, the dyed structures were dissected and isolated for photo documentation and identification (technique adapted Lécuru et al. 1997). The lymph nodes were processed for histology. Fixed tissues were prepared following standard histological techniques and embedded in paraffin. Tissue sections approximately 7- $\mu \mathrm{m}$ thick were stained using Harris hematoxylin and eosin (HE). The histological sections were examined by Moticam 2000 2.0 M Pixel USB (Manufactured by: MRC International, Holon, Israel).

To perform the transoperative experiments, the bitches were subjected to preoperative and postoperative screening test. Only the bitches that had preoperative test results inside the normal limits were subjected to ovariohysterectomy (Viana 2007). Sedation was achieved using acepromazine $(0.03 \mathrm{mg} / \mathrm{kg})$ and morphine $(0.5 \mathrm{mg} / \mathrm{kg})$, both administered intramuscularly 25 minutes before the procedure. Anesthesia was induced using propofol (5mg/kg IV) and maintained using isoflurane administered by inhalation. Analgesia was provided by subcutaneous injection of

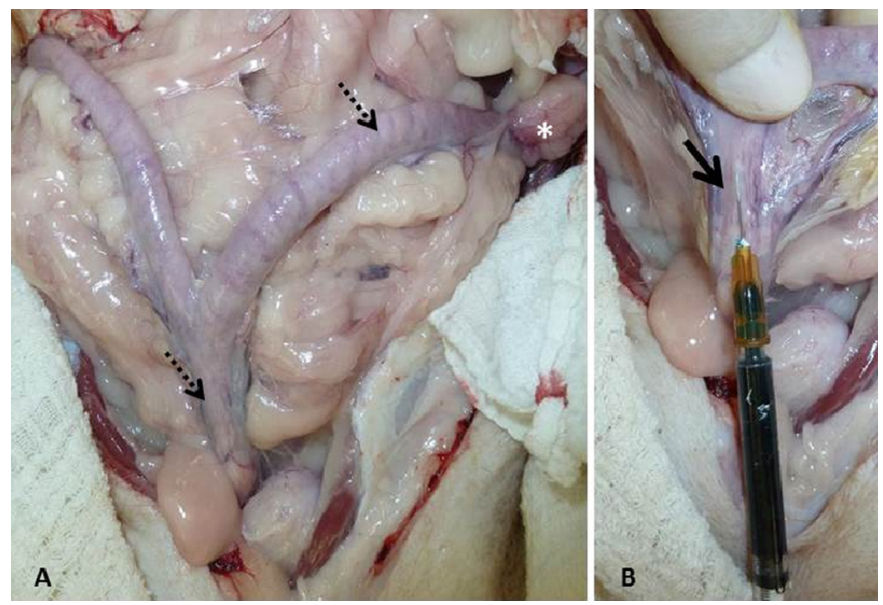

Fig.1. Uterine application of the blue dye in experiment using cadavers. (A) Dashed arrows indicate applications sites of patent blue in the uterus body and medial third of the horns. Is possible to observe also the left ovary (*). (B) Patent blue $\mathrm{V}$ was injected into the subserosal layer of the uterine body (Arrow). 
a non-steroidal anti-inflammatory drug (ketoprofen) at $1 \mathrm{mg} / \mathrm{kg}$. Preventive antibiotic therapy was performed by intravenous administration of $30 \mathrm{mg} / \mathrm{kg}$ cephalothin and maintained for 7 days with oral administration of the same dose of cephalexin every 8 hours. A celiotomy was performed and the uterus was located and isolated. Using a $1 \mathrm{~mL}$ syringe and an insulin needle, 0.4 to $0.6 \mathrm{~mL}$ of patent blue was injected into the subserosal of the horns and uterine body (ventral) (Fig.2). After the injections, the site was massaged, and 5 minutes afterward, the cavity was inspected to locate the nodes responsible for uterine drainage (surgical technique adapted from Altgassen et al. 2007). After the inspection and photo documentation, we applied the standard technique of ovariohysterectomy. Postoperative analgesia was achieved using meloxicam in a dose of $0.1 \mathrm{mg} / \mathrm{kg}$ every 24 hours for 4 days.

Because this study focused on describing the characteristics of the lymphatic physiology of the canine uterus, no statistical tests were performed. A descriptive analysis and photo documentation of the results were performed.

\section{RESULTS}

After infusion, the blue dye reached the lymphatic vessels along the round ligament of the uterus (Fig.3). While inspecting the abdominal cavity with emphasis on the retro-
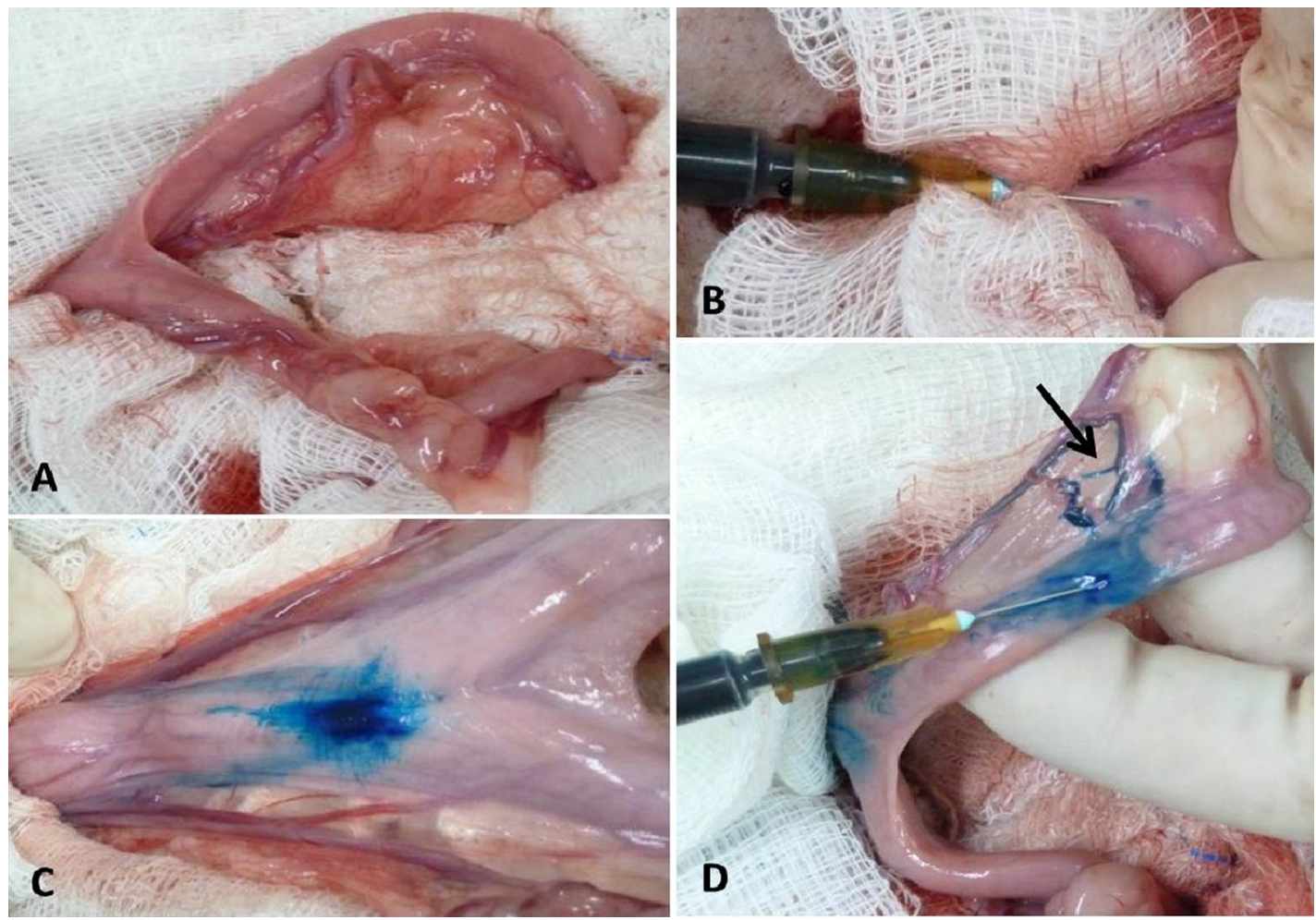

Fig.2. Uterine application of the blue dye in experiment during ovariohistectomy. (A) Isolation of uterus.

(B) Patent blue V infusion into the subserosal layer of the uterine body. (C) Dye diffusion through the tissue after application. (D) Immediately after application it is possible to observe lymphatic channels (Arrow).
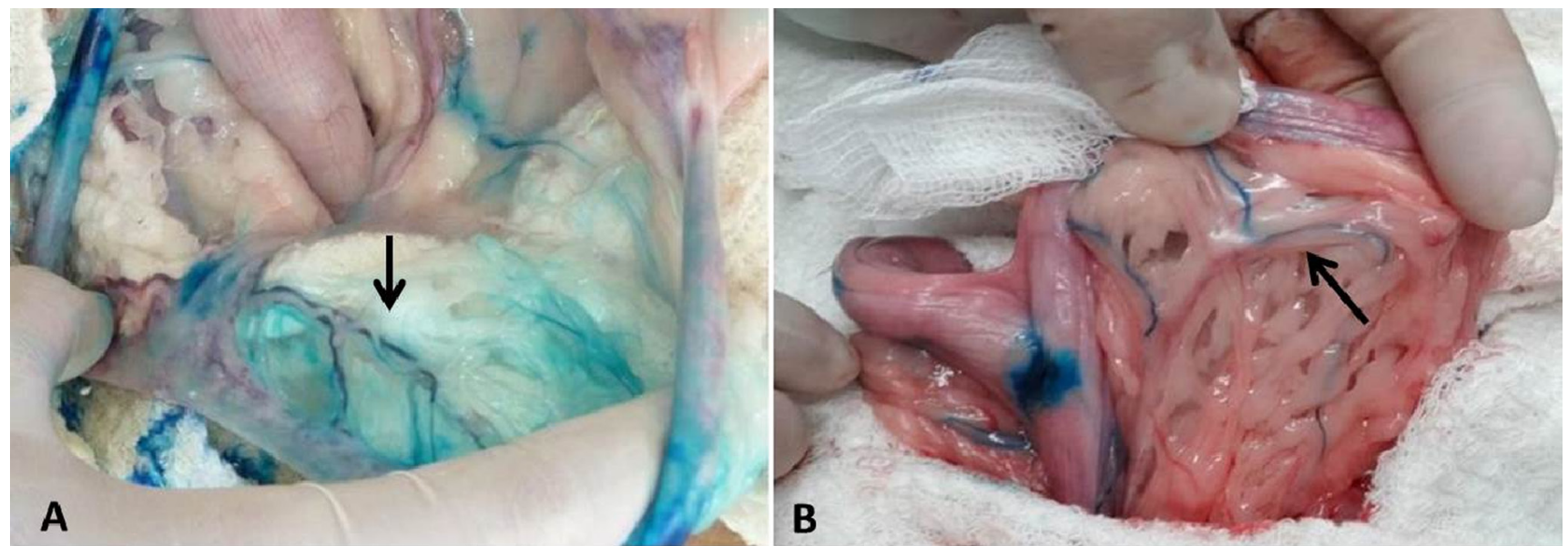

Fig.3. Comparison of results obtained from cadavers and animals during surgery. Arrows indicate lymphatic channels observed in: (A) Cadavers and (B) animals during surgery. Both stained with patent blue V. 
peritoneal region, it was found that part of the lymphatic drainage of the uterine horns was received by medial iliac lymph nodes. The results obtained from the examining the animals during surgery were consistent with those obtained from the cadavers. It was possible to perform a detailed inspection of the cadavers, including dissecting and removing the dyed structures for histological confirmation that they were lymphatic tissues (Fig.4). In the animals exami- ned during surgery, the turquoise color was observed beneath the peritoneum and within adipose tissue in the region where the medial iliac lymph nodes are located (Fig.5).

The uterine body appeared to drain into the internal iliac and sacral lymph nodes, due to the path of the dye in the lymphatic vessels (Fig.6). The cranial region of the uterine horns also displayed a different pattern of drainage, likely to the aortic and renal lymph nodes (Fig.7).
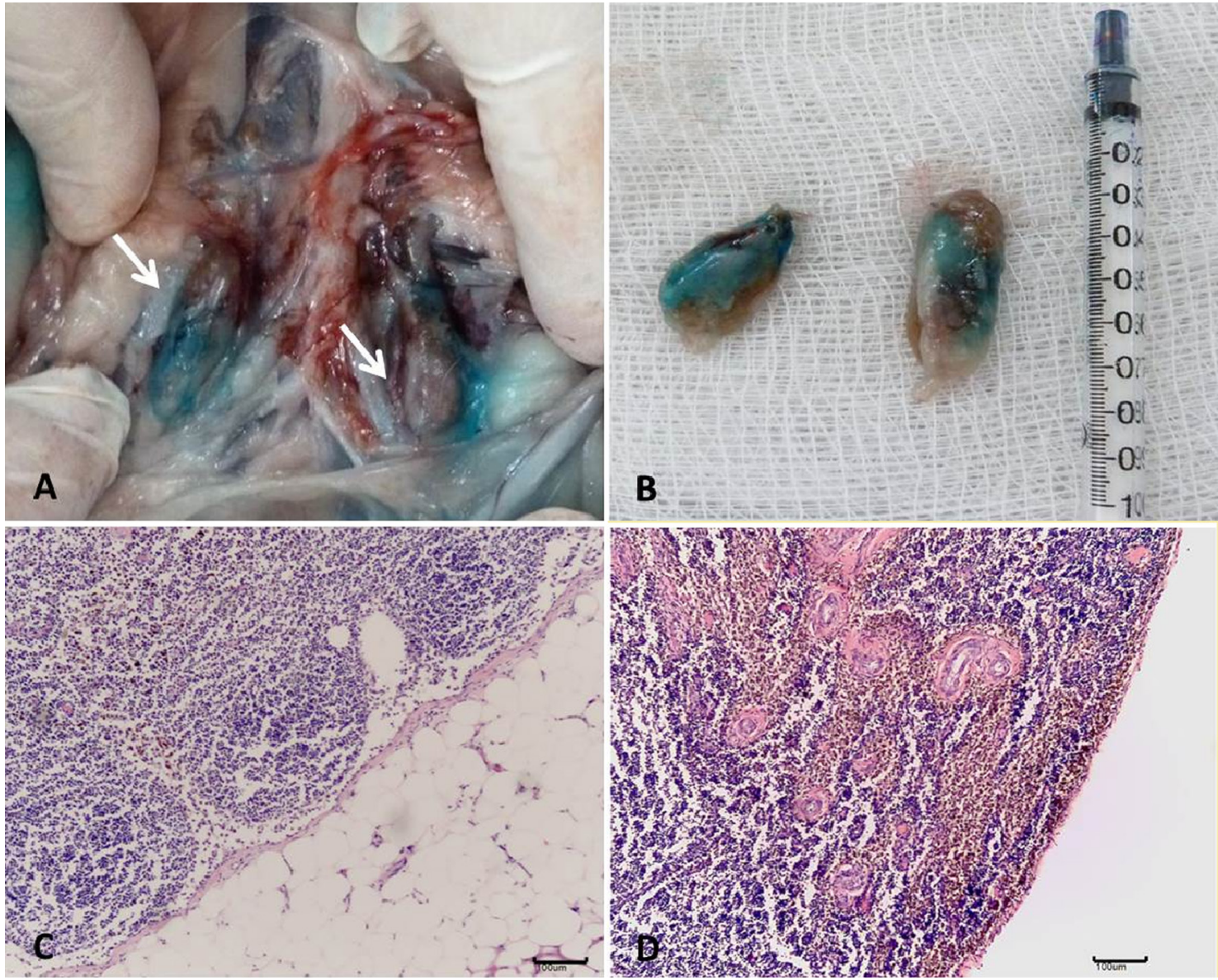

Fig.4. Detailed inspection of the cadavers. (A) Dissection and (B) Removal of the dyed structures. (C,D) Histological confirmation that they were lymphatic tissues (observed in 10x).
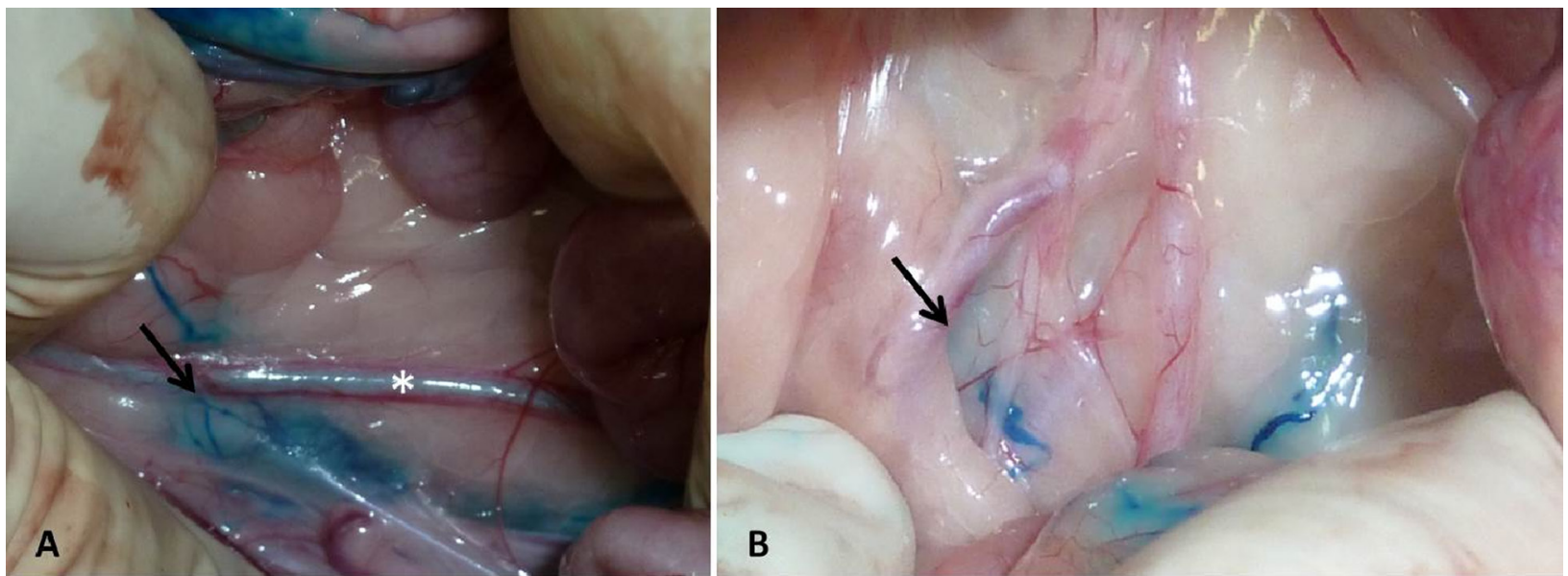

Fig.5. (A,B) Turquoise color beneath the peritoneum and within adipose tissue in the region where the medial iliac lymph nodes lymph nodes located (arrows) in two different bitches. It is possible to observe also the ureter $(*)$. 
urine within 3 days following the surgical procedure and mapping.

As previously mentioned, the medial iliac lymph nodes were not the only lymph nodes that participate in the uterine lymphatic drainage. The internal iliac and sacral lymph nodes appeared to be responsible for part of the uterine drainage. An osteotomy of the pelvis was not performed for better inspection of the region because the focus of the experiment was to locate the lymph nodes that could subsequently be examined using non-invasive methods, such as ultrasonography.

The evidence that the pattern of dye diffusion that we observed in live animals was repeated in cadavers favors the use of this technique in studies that involve inspection of the abdominal cavity and increases the safety of anatomical-topographical location of the medial iliac lymph nodes and their dissection because the region in question is closely linked to the great vessels (aorta and vena cava) and

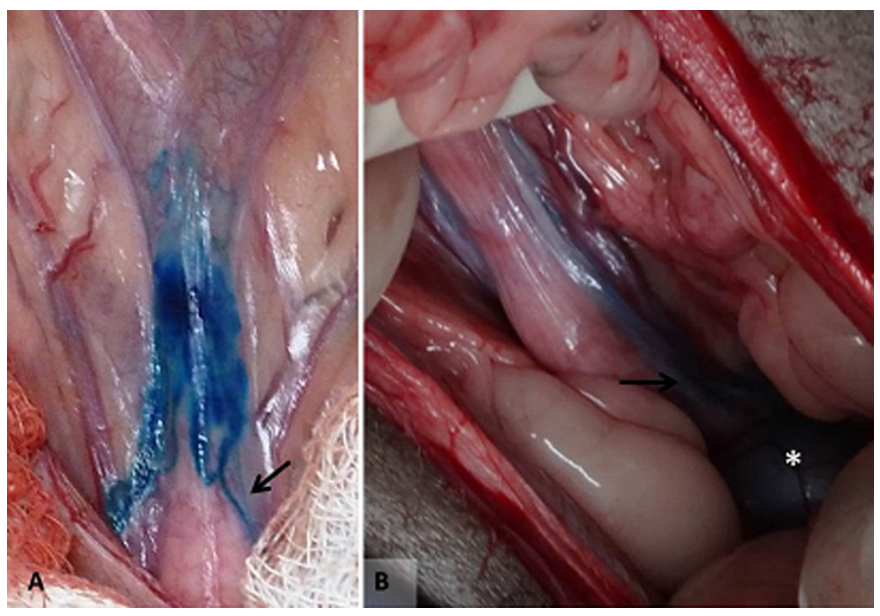

Fig.6. (A,B) Drainage of uterine body. Turquoise staining in lymphatic channels that drain into lymph intrapelvic (Arrows) and bladder $\left(^{*}\right)$.
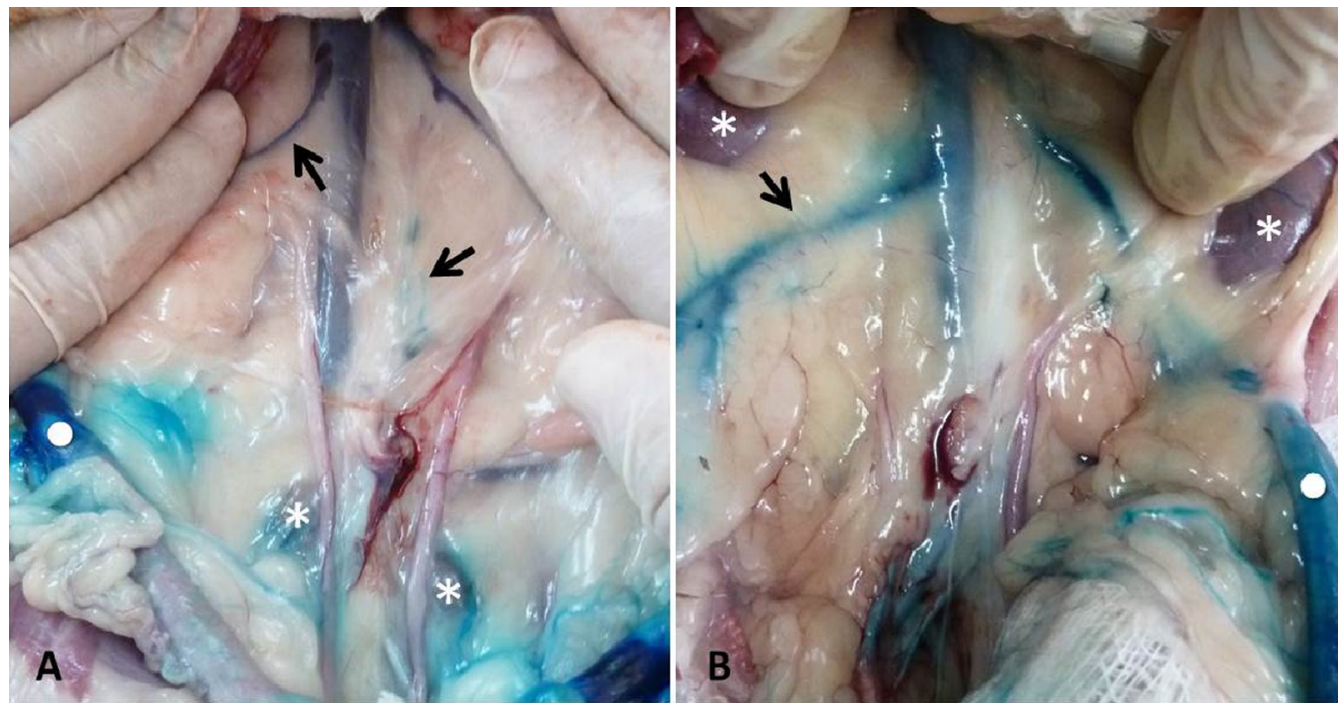

Fig.7. Drainage of cranial and medial area of uterine horns. It is possible to observe the uterine horn (spheres), stained lymphatic channels that drain into the renal and aortic lymph nodes (arrows), $\left(\mathbf{A}^{*}\right)$ the medial iliac lymph nodes and $\left(\mathbf{B}^{*}\right)$ both kidneys.

\section{DISCUSSION}

Patent blue $\mathrm{V}$ belongs to the triphenylmethane dye family and chemically corresponds to the sodium salt of bis (dietilamino-4-fenil) (hidroxi-5-dissulfo-2,4-fenil) methanol anhydride; its only limitation is that patients can be hypersensitive to patent blue $\mathrm{V}$ sodium salt (patient information leaflet). None of the animals used in this study exhibited immediate or late hypersensitivity reactions such as those described in the literature in humans (Del massa et al. 2005, Shinzato et al. 2006, Jeudy et al. 2008, Bricou et al. 2009, Hunting et al. 2010, Lucas et al. 2010, Rodrigues et al. 2010, Hou-Chuan Lai et al. 2011). According to the patient information leaflet, whatever is the route of administration, the Patent Bleu $\mathrm{V}^{\circledR}$ solution $(2.5 \%)$ is excreted within 24 to 48 hours in the bile and urine, the latter being more strongly colored. More than half of the bitches used in the intraoperative experiment had blue urine in the immediate postoperative period. All of the bitches had bluish the risk of bleeding is high. The results showed that the patent blue $\mathrm{V}$ dye effectively demonstrating that the medial iliac lymph node chain is the sentinel chain of the uterine horns of bitches. In addition, the use of cadavers obtained soon after natural death or euthanasia allowed a more detailed study of the uterine lymphatic drainage.

Acknowledgments.- The authors express their gratitude to Prof. Ana Paula F.R.L. Bracarense, the employees and residentes of the Laboratory of Pathology, Veterinary Hospital, State University of Londrina (HV/UEL), for providing the facilities to carry out the experimente with cadavers. To the employees and residents of the surgical center of HV/UEL, who assisted in conducting the experiment during surgery. To the Post Graduate Program in Animal Science UEL, for the financial support. To Coordination of Improvement of Higher Education Personnel (CAPES), for granting the scholarship masters.

\section{REFERENCES}

Altgassen C., Pagenstecher J., Homung D. \& Hornemann A. 2007. A new approach to label sentinel nodes in endometrial câncer. Gynecol. Oncol. 105:457-461. 
Baum H. 1918. Das lymphgefassystem des hundes. Arch. Wiss. Prakt. Tierheilk. 44:521-650.

Bin Li, Xiao-Guang Li, Ling-Ying Wu, Wen-Hua Zhang, Shu-Min Li, Cheng Min \& Ju-Zhen Gao. 2007. A pilot study of sentinel lymph nodes identification in patients with endometrial cancer. Bull. Cancer 94:1-4.

Bricou A., Barranger E., Uzan S. \& Darai E. 2009. Anaphylactic shock during the sentinel lymph node procedure for cervical cancer. Gynecol. Oncol. 114:375-376.

Burke T.W., Levenback C., Tornos C., Morris M., Wharton J.T. \& Gershenson D.M. 1996. Intraabdominal lymphatic mapping to direct selective pelvic and paraaortic lymphadenectomy in women with high-risk endometrial cancer: results of a pilot study. Gynecol. Oncol. 62:169-173.

Cave T.A., Hine R., Howie F., Thompson H. \& Argyle D.J. 2002. Uterine carcinoma in a 10-month-old golden retriever. J. Small Anim Pract. 43:133135.

Cowell R.L., Dorsey K.E. \& Meinkoth J.H. 2003. Lymph node cytology. Vet. Clin. North Am., Small Anim. Pract. 33:47-67.

Del Massa E.C., Grion L.F.C. \& Ghaname N.S. 2005. Reação alérgica ao corante azul patente. São Paulo Med. J. 123:53.

Echt M.L., Finan M.A., Hoffman M.S., Kline R.C., Roberts W.S. \& Fiorica J.V. 1999. Detection of sentinel lymph nodes with lymphazurin in cervical, uterine and vulvar malignancies. South Med. J. 92:204-208.

Ficher H.W. \& Zimmerman G.R. 1959. Roentgenographic visualization of lymphnodes and lymphatic channels. Am. J. Roentgenol. Radium Therapy Nucl. Med. 81:517-534.

Fontaine E., Levy X., Grellet A., Luc A., Bernex F., Boulouis H.J. \& Fontbonne A. 2009. Diagnosis of endometritis in the bitch: a new approach. Reprod. Domest. Anim. 44:196-199.

Freitas A.H.A. 2007. Pesquisa de linfonodo-sentinela em pacientes com adenocarcinoma de cólon. Dissertação de Mestrado, Universidade Federal de Minas Gerais, Belo Horizonte. 77p.

Gould E.A., Winship T., Philbin P.H. \& Kerr H.H. 1960. Observations on a "sentinel node" in cancer of the parotid. Cancer 13:77-78.

Hou-Chuan Lai, Huan-Ming Hsu, Chen-Hwan Cherng, Shinn-Long Lin, Ching-Tang Wu, Jyh-Cherng Yu \& Chun-Chang Yeh 2011. Interference of patent blue dye with pulse oximetry readings, methemoglobin measurements, and blue urine in sentinel lymph node mapping: a case report and review of the literature. Acta . Taiw. 49:162-164.

Hunting A.S., Nop A., Johansson S.G., Andersen F., Wilhelmsen V. \& Guttormsen A.B. 2010. Anaphylaxis to patent blue V. I. Clinical aspects. Allergy 65:117-123.

Jeudy G., Louvier N., Rapennes T., Goujon E., Fraisse J., Dalac-Rat S. \& Collet E. 2008. Immediate patent blue-induced hypersensitivity during sentinel node detection: the value of cutaneous tests. Ann. Dermatol. Venereol. 135:461-465.

Johnston S.D., Kustritz M.V.R. \& Olson P.N.S. 2001. Disorders of the canine uterus and uterine tubes (oviducts), p.206-224. In: Ibid. (Eds), Canine and Feline Theriogenology. W.B. Saunders, Philadelphia.

Klein M.K. 2007. Tumors of the female reproductive system, p.614. In: Withrow S.J. \& Vail D.M. (Eds), Small Animal Clinical Oncology. $4^{\text {th }}$ ed. Elsevier Saunders, Philadelphia.
Lécuru F., Neji K., Robin F., Darles C., De Bièvre P. \& Taurelle R.J. 1997. Lymphatic drainage of the uterus. Preliminary results of an experimental study. Gynecol. Obstet. Biol. Reprod. 26:418-423.

Levenback C., Coleman R.L., Burke T.W., Lin W.M., Erdman W., Deavers M. \& Delpassand E.S. 2002. Lymphatic mapping and sentinel node identification in patients with cervix cancer undergoing radical hysterectomy and pelvic lymphadenectomy. J. Clin. Oncol. 20:688-693.

Lucas N., Interne S.B., Laine P., Nicolie B. \& Fondrinier E. 2010. Choc anaphylactique et bleu patente : à propos de quatre cas et revue de la littérature. J. Gynecol. Obstet. Biol. Reprod. 39:116-120.

Mir F., Fontaine E., Albaric O., Greer M., Vannier F., Schlafer D.H. \& Fontbonne A. 2013. Findings in uterine biopsies obtained by laparotomy from bitches with unexplained infertility or pregnancy loss: an observational study. Theriogenology 79:312-322.

Pretzer S.D. 2008. Clinical presentation of canine pyometra and mucometra: a review. Theriogenology 70:359-363.

Rodrigues M.A.P.A., Mazoni A.C.O., Carneiro P.C.A., Haeffner J.C. \& Neto A.A. 2010. Efeito adverso do corante azul patente em paciente com câncer de mama, submetida à segmentectomia e biópsia de linfonodo sentinela (ls): relato de caso. Revta Assoc. Med. Flumin. 43:18-19.

Rouviére H. \& Valette G. 1937. Physiologie du Systéme Lymphatique. Masson et Cie, Paris.

Sant’Anna M.C. 2012. Avaliação prognóstica da piometra canina. Dissertação de Mestrado, Universidade Estadual de Londrina, Londrina. 51p.

Shinzato J.Y., Marcaccini A.C.P., Braga A.F.A., Ribeiro A.R., Rubio J.E.M. \& Souza J.P.D. 2006. Reação anafilática ao corante azul patente durante a biópsia do linfonodo sentinela em câncer de mama inicial: relato de caso. Revta Bras. Ginecol. Obstet. 28:728-732.

Skelley J.F., Price J.E. \& Koehler R. 1964. Applications of direct lymphangiography in the dog. Am. J. Vet. Res. 25:747-55.

Tanis P.J., Nieweg O.E., Valdés Olmos R.A., Th Rutgers E.J. \& Kroon B.B. 2001. History of sentinel node and validation of the technique. Breast Cancer Res. 3:109-112.

Tivers M.S., Selmic L.E., Scurrell E.J., Baines S.J. \& Smith K.C. 2009. Haemangiosarcoma in the uterine remnant of a spayed female dog. Small Anim Pract. 50:488-491.

Tsioli V.G., Gouletsou P.G., Loukopoulos P., Zavlaris M. \& Galatos A.D. 2011. Uterine leiomyosarcoma and pyometra in a dog. J. Small Anim. Pract. 52:121-124.

Viana F.A.B. 2007. Guia Terapêutico Veterinário. $2^{2}$ ed. Lagoa Santa, Minas Gerais.

Wang H., Tan Y., Wang X. \& Xie J. 2001. Identification of pelvic lymph nodes with chlorophyllin after injection into the uterine cervix: an experimental and clinical study. Lymphology 34:69-76.

Watts J., Wright P. \& Lee C. 1998. Endometrial cytology of the normal bitch throughout the reproductive cycle. J. Small Anim. Pract. 39:2-9.

Weiss R.R., Calomeno M.A., Sousa R.S., Briersdorf S.M., Calomeno R.A. \& Muradás P. 2004. Avaliação histológica, hormonal e bacteriológica da piometra na cadela. Archs Vet. Sci. 9:81-87.

Wong J.H., Cagle L.A. \& Morton D.L. 1991. Lymphatic drainage of skin to a sentinel lymph node in a feline model. Ann. Surgery 214:637-641. 